\title{
Criminal Protection of the Family in Iran's Law in Light of the Latest Code
}

\author{
Gholam Reza Shirazi ${ }^{1}$, Keyoumars Kalantary ${ }^{2} \&$ Abolhasan Shakeri ${ }^{2}$ \\ ${ }^{1}$ University of Mazandaran, Iran \\ ${ }^{2}$ Faculty of Law, University of Mazandaran, Babolsar, Iran \\ Correspondence: Gholam Reza Shirazi, Doctor of criminal law and criminology candidate in University of \\ Mazandaran, Iran. E-mail: shirazi.1lb@gmail.com
}

\author{
Received: April 5, 2016 Accepted: May 10, 2016 Online Published: June 29, 2016 \\ doi:10.5539/jpl.v9n5p40 URL: http://dx.doi.org/10.5539/jpl.v9n5p40
}

\begin{abstract}
According to Iranian legislation, the family is the basic unit and all the codes and rules must be enacted to support and protect it. This article discusses the known crimes and penalties that support the family institution according to Iran's penal code. The method used in this article is library-descriptive and it is done in content-analysis style. In this paper, based on the latest Family Protection Code, we analyzed the criminalized behaviors and actions that damage the family. The investigation concludes that some actions and behaviors are correctly criminalized while some others can receive more suitable responses through non-criminal measures such as psychological and counseling systems. In some cases the legislator has imposed sever response against criminal actions. Besides, it is found that measures preventing criminalization may preclude secondary victimization.
\end{abstract}

Keywords: family institution, criminal protection, victimization, criminalized behavior

\section{Introduction}

The family is the smallest but the most important social unit that has been formally accepted in every society. Without considering the cultural differences which play an important role on the form and structure of family institution, the function of the family is quite similar in all societies. The most important functions of family are reproducing and educating, creating a loving and safe environment for the couples and a motivation for economic activities. The family can be divided into different types such as extended and immediate. The extended family had an important role due to the need for labor. Today, although some traditional and rural societies still feature extended families, urbanization has seen the increase of immediate families. The immediate family consists of the parents and unmarried children.

In most countries there are rules for recognizing family rights and methods for its protection. Social security of families must be the motivation of authorities for protecting the family. Any law, concerning the family, which is passed by the authorities can either strengthen or weaken this institution. Without any doubt the authorities must consider each member of family but the welfare of the family as an institution must be considered and its protection must be given the highest priority.[1:p,15]

The family is the first public and international systematic institution which plays an important role in emotional and vital needs and survival of the society. Besides, it is the strongest and the most natural institution. [2:p, 599.] The family which is the smallest fundamental unit of any society is studied from different point of views. Family plays an important role in development and securing of the power of nation. In other words, there is a very close relation between power of the nation and the family. The fall of the families of nations, whereas the most powerful nations are those in which the family is fundamental. History leads to the fall demonstrates that the weakening of the family coincides with the fall of civilizations.

The survival of humanity is conditioned upon the existence of the family. The advances of every society are the direct results of efforts and endeavors of families that do not withhold from any sacrifice in correct education of their children. In other words, the family not only is the natural pillar of the society but also its fundamental column as well.[3:p,16]

It's probably the instability of families has led to legislation which helps the stability of the family institution. 
This research reviews the family protection methods with criminal penal code according to current rules and regulations of the Islamic Republic of Iran.

The general aim of this research is to review and analyze criminal laws related to the family institution and also to gather information on methods of criminal protection of this institution based on current rules and regulations of Islamic Republic of Iran.

The hypothesis of the research: Iran's Islamic Penal Code protects the family institution by providing guarantee for enforcing sentences.

Methodology: The method used in this research is library-analytic and after gathering information and resources and reviewing regulations, the scientific analysis of the related law is carried out.

\section{A. Criminalization of disorder in the family system}

Since it has been the responsibility of authorities to protect the society against criminals [4:p,5], the protection of family as the microcosm of society must also be among the responsibilities of governments. These days the authorities have accepted this responsibility but the practical measures taken for family protection are always open to discussion. Criminal sanctions should always be used as a last resort, especially in the law related to the family institution, which its creation must be based first on love between the man and the woman and second on a bond between the couples. Criminalization is a process that the legislature uses to pass laws, according to which actions are considered crimes against the social values and public order. The Islamic Penal Law in Iran describes crime in its Article 2 as follows: "any action or avoidance of an action which has a punishment in the law system is a crime". It is clear that culpability is not an inherited and innate quality of a specific behavior but just a description that others relate in an emotional reaction. Therefore crime is a social phenomenon that that has its origin in society in society and the penal law has been created for dealing with this phenomenon.

Criminalization is a mechanism for prevention of crimes based on social and individual prevention and if the legislature fails in providing an appropriate guarantee for enforcing sentences, it will disable the preventive role and function of the law [5:p, 78]

While accepting the factor that the nature of family is not compatible with imperative laws and regulations and the influence of law in creating family stability is minimal, "the family institution is studied and analyzed.

The Penal Code of Islamic Republic of Iran has described some actions as crimes under the title "crimes against family rights and responsibilities", in chapter 19, articles 642 to 648 and 'these actions will be reviewed and analyzed.

\section{1) Relinquishment of maintenance}

Article 642 states "Any husband failing to pay the alimony of his wife or any other dependent, while having financial ability, can be sentenced to imprisonment from six months up to two years"

This article oversees article 1106 of the civil code which makes the husband responsible for the alimony of the wife. It states: "in a permanent marriage, the alimony of the wife must be paid by the husband". Article 1107 of the civil code, amended on November 10, 2002 describes alimony as follows:

"All the financial needs of the wife depending on her social status including accommodation, food, furniture, clothes, medical and treatment expenses as well as the cost for a servant if needed while being ill or disabled".

It is quite evident that limiting alimony is not compatible with family expediency, social necessity and the cases stipulated in tradition [6:p,214]. From the Islamic law point of view, it is among the responsibilities of the husband to provide for the wife and the wife has no responsibility in this matter; this include all aspects regardless of her financial ability to provide for herself. She might be wealthy but it is not necessary that she support herself [7: $p, 288]$. Therefore what the wife receives from the husband as alimony must be on a standard basis, meaning what the tradition rules. Similarly the wife's social status must be taken into consideration for determining the value, amount and type of alimony; in other words, the alimony must be equal to the alimony of others with the same social class.

In article 642, the responsibility of financial support and alimony payment of two groups are given to the husband. The first group is the wife or the wives of the husband and the second, as clearly stated in article 1196 of the civil code, the relatives of the husband, either older or younger, meaning the parents and the grandparents and children or grandchildren. 'The question of priority of payment has been answered clearly by article 1203 of the civil code as follows:

In case of a group of people, all qualifying for receiving alimony, the wife has the highest priority. Crimes 
relating to article 642 are of omission or action of both the following conditions:

a. Financial ability of the husband who the payment of alimony has been determined for by the law. The proof of his financial ability is by the plaintiff since the lack of financial ability is deniable and cannot be proven.

b. Obedience of the wife: obedience has two general and specific meanings. In the specific sense means, the consent of the wife to have sexual intercourse with the husband; however this is the responsibility of both parties.

In the general sense it means to accept the husband as the decision maker and head of the family and obey him within the boundaries of the law and tradition, in other words, all the responsibilities of the wife towards the husband is called obedience in the general sense. Therefore at any time the wife fails to obey the husband, the husband has the right to ask the court for her obedience, Should this condition be affirmed the right of receiving alimony will be canceled.

With the occurrence of both the above-mentioned conditions and avoidance of the action , alimony payment, which is a private crime and requires a private plaintiff, cancelation of prosecution needs reconciliation of both the parties. Therefore according to article 727 of the Islamic Punishment Code, supervising article 642, the penal action can be pursued unless the wife withdraws her complain. Relinquishment of maintenance is a continuing crime. [8:p, 212] The crime location is the place of residence of the husband or any other place that he is arrested. In other words, this crime is being committed from the place of residency of the husband to the place where he is arrested and the authorities of both locations have the right and jurisdiction to prosecute the husband. The date of pursuit does not give priority and determine the jurisdiction for arrest and the location of the husband is the sole factor is determining the right for prosecution. If the husband has more than one wife and all of them have filed a separate complaint against him for relinquishment of maintenance and a guardian of minor child also files a complaint on the same basis, each complaint will be settled on its own and the court must make decisions on the matter, while considering that the crime is similar. In relation to this and based on article 47 of the Islamic Penal Code, since the committed crimes are all similar and of the same kind, only one punishment will be determined but the multiplicity of crimes can increase the severity of punishment.

2) Crime of marrying a married woman to a third person:

According to article 643 of the Islamic Penal code: "If someone knowledgeably concludes marriage of a married woman or a woman who is in legal term of abstention of a widow or a divorcee of a man, to a third person, he will be sentenced from six months up to three years of imprisonment and fined between 3,000,000 to 18,000,000 Rials and condemned up to 74 lashes and his license for a marriage, divorce or notary registration office will be revoked permanently". For occurrence of crime, violation of law and orders of the legislator by itself is not enough, and a criminal act should occur intentionally. $\mathrm{n}$ other words, there should be a relationship between the crime committed and the psychic status of the criminal in order to hold him responsible for his crime [8, p.233]. The three, legal, material and spiritual factors of this crime, marrying a married woman to a third person, are here at once. The legal element is the content of article 643. The material element of the crime refers to the conclusion of marriage and spiritual or sinister intention can be implied from the word "knowledgeably". So, knowledge of the concluder on the state of woman for being married or being in the term of widowhood proves his guilt. Legal term of abstention in this article refers to period of abstention of wife in case of irrevocable or revocable divorce or in case of husband's death, and the word "knowledgeably" in the heading of the article, in case of the lack of knowledge of the criminal on the marital status of the woman, he will be exempted from the responsibility $[9$, p.360].

3) The crime of marrying a married woman to a third person or marrying her for oneself:

Criminalization of the above-mentioned behavior is acted according to article 644 of the Islamic Penal code " people who knowledgeably do one of the following acts, will be jailed for a period of six months up to two years or fined from 3,000,000 to 12,000,000 Rials: a) Any woman who is in marriage or abstention of a man, and marries another man even if the marriage does not lead to sexual intercourse, b) Any man who marries a woman, while she is married or in abstention of a man, even if the marriage does not lead to sexual intercourse". The crimes subject to article 643 and 644 refer to the crimes occurring after marriage and the subject is understood from the words mentioned in the above articles. The word "married woman" or " a woman who is in abstention of another man" shows the fact. The crime in both cases refers to permanent and temporary marriages and its type does not affect the occurrence of the crime.

The word "knowledgeably" in the heading of the article 644 emphasizes on the spiritual element or sinister intention which it is not to be proved about a married woman or a woman who is in abstention of another man 
because the criminal act may have one or two criminals and certainly, the woman is criminal because she absolutely knows the fact about her status but the other man, may not be aware of the state of woman for being in term of marriage or abstention of another man and in this case, man is not responsible for the occurred criminal act. Sexual intercourse in article 644 refers to the act of adultery and the verdict for this article is valid before the occurrence of sexual intercourse and incase of occurrence of sexual intercourse, punishments related to the act of adultery will be executed.

4) The crime of not registering a marriage, divorce and revocation of divorce:

In order to keep the foundation of family, registration of marriage, divorce and revocation of divorce is required by virtue of article 645. "If a man marries, divorces or revokes a divorce without registering it will be jailed up to one year".

The crime mentioned in article 645 is of avoidance of an action and a continuing crime and the man is continuously committing the crime while his marriage/divorce is not registered. The majority of present members, in legal meeting of the Judiciary, agree to issue a warrant of prosecution for the husband if he fails to register his marriage/divorce and no liability should be given to the marriage or divorce pronouncer. The crime mentioned in this article is only for husbands engaged in a permanent marriage. Therefore there is no need for registering a temporary marriage. The husband, in order to protect the rights of the couple, is responsible for registering a permanent marriage or divorce instance in order to be able to prove the marriage relation or its termination.

\section{5) The crime of marriage before puberty}

According to article 646, "marriage before the age of puberty without the consent of the guardian is forbidden and any person marrying a girl before her puberty age can be sentenced from six to two years of imprisonment."Marriage in this article refers to both permanent and temporary marriage and guardian here means, the father or paternal grandfather. The content of article 1040 amended on June 22, 2002 by the Expediency Discernment Council of the System states that "marring a girl before the age of 13 and a boy before the age of 15 requires the consent of their guardian while being expedient upon the approval of the court"

Article 1041 of the civil Code has determined the age of puberty, 13 for the girls and 15 for the boy. Therefore if any man marries a girl before this age without the consent of her guardian or the court is a criminal and is subject to article 646 of the Penal Code. The question here is if the same rule and crime applies to a woman marry a boy before his age of puberty? The answer to this question, based on limited interpretation of criminal law, is negative and it is clearly stated in the content of article 646 "if a man..." therefore the law will not apply to a woman marring an underage boy. [9:p,361] Any puberty girl, who has been wed with the consent of her father but without the permission of a court, can apply for a nullity of marriage through the court .

6) The crime of deception in marriage

The last article concerning the crimes against family and its responsibilities is article 647 which states "if any of the parties deceive the other on unreal affairs such as the level of education, financial ability, social class, job or a special position and celibacy and marriage incidence happens, the guilty party can be sentenced from six to two years of imprisonment."The criminalization of behavior mentioned in this article is concerned with the family institution at its formation stage and either of the parties, man or woman can be guilty. The said affairs in this article are all allegorical and there can be other affairs which the parties may lie to and deceive the other. This crime can only be committed by one of the couple and if a third party, like a family member, deceive either of the couple, the conditions of this crime is not met and even if a marriage incidence is registered based on a false attribute and the person has knowledge of this but withholds from the other party, will not be subject to this article. The legal administration of the Ministry of Justice in the letter number 7/4057 issued on October 29, 1985 stated: falsifying any record of previous marriage is a crime, therefore if any virgin woman hides her pervious marriage or divorce incidence has committed deception in marriage and will be subject to article 647 of Islamic Penal Code but this will not result in decreasing her marriage portion. There are two solutions for deception in marriage, the deceived party can apply through penal court, based on article 647 and the deceiving party will be sentenced from 6 to 2 years of imprisonment or apply through legal court for annulment of marriage. Annulment does not require the formalities of a divorce and the deceived party can easily apply for annulment of the marriage.

\section{7) Adultery}

In addition to the mentioned six articles above, there are other issues in the Islamic Penal Code which either directly or indirectly supports family rights on criminal grounds, among many; article 83 and 857 can be 
mentioned. Article 83: "Islamic punishment for adultery in the following conditions is stoning to death:

a. Adultery committed by a married man, any man who is permanently married to another woman and she is in perfect mental health and he can have sexual intercourse with her any time he wants to.

b. Adultery committed by a married woman with another adult man, a married woman is a woman who is permanently married to a man and while she is in perfect mental health, they can have sexual intercourse any time they wish to.

Note: punishment for adultery committed by a married woman with an underage child is lashing."

Article 857: "if any man catches his wife having sexual intercourse with another man and is sure that she is not being raped can kill them both there and then and if the wife was made to have sexual intercourse with the man, the husband can only kill the man. Punishment for assault and battery here is the same as murder". In both the above-mentioned articles, exemption from murders and assault and battery charges are there to support family institution on criminal grounds. According to this, a criminal is a person who his actions weaken the foundation of family.

B. Punishment relaxation or conversion of punishment due to family relations

The legislature, in some cases, can relax the punishment rules or convert the punishment of criminals for protecting the foundation of family and preventing families from more serious victimizing, in the cases of inner family criminals. These include:

1) The note of article 785 of the Islamic Penal Code states if the criminal is the one who helps the criminal to hide or escape or helps the criminal to get rid of the trial, and he is of the criminal's family, the punishment will not be more than half of the maximum determined punishment.

2) By virtue of paragraph 11 of article 198 of Islamic Penal Code, of the thief is father of the property owner, the Islamic punishment will not be performed and the punishment will be changed to limit rubbery punishment.

3) In article 220 of the Islamic penal Code, if father or grandfather kills his son, he will not be retaliated, and he will be forced to pay blood money to the heirs of victim and condemned to limit punishment.

C: Victimology of anti-family institution crimes:

Traditional penal laws are based on three principles: crime, the criminal and social reaction against the crime (punishment). For years, criminal phenomenon has been highly attended and any anti-social behaviors were faced with serious punishment and the criminals were punished, coercively. Coercive behavior toward the criminals, led the scientists to protect rights of the criminals in a way that they searched justice in reaction against the criminals. Considering all these, the victims were disregarded through the process. Developments of 1960s and 1970s resulted in paying attention to the victims to the extent that nowadays, we are talking about victim oriented penal law.

The word victim refers to a person who is physically, psychologically, emotionally, financially, painfully or basically suffered due to a crime, occurred on his fundamental rights. Considering the word person, victim refers to a legal or actual person [5, p.16]. Sometimes legal and actual persons may become suffered in the same time. Accordingly, we tend to investigate victimization of the family as a unit-legal personality- in the previous criminalizing cases.

1) In the crime "relinquishment of maintenance", considering that the crime is in the group of venial crimes and they cannot be pursued unless it has private plaintiff and in this case, wife is the victim, not the family as an independent legal entity.

It is to be noted that in case of failure to pay relinquishment of maintenance, wife and children will have financial problem, in this case the word victim directly refers to wife and children and indirectly refers to the family as an independent legal entity. It is because if the direct effect of relinquishment of maintenance is imposing difficulties on wife, the indirect victimization imposed by some institutions such as police, criminal justice system and court, causes the family institution to be secondary victim.

2) Legislator accurately criminalized the crime of marrying a married woman to a third person because the real victim of this criminal act is the family and that is why, the legislator put this crime in the group of non-venal crimes and the government supports it. In this case, the criminal knowledgeably disintegrates the family.

3 ) In the crime of marrying a married woman or marrying a married woman to a third person, family is the real victim. The word "married woman" refers to a family and the criminal act of married woman basically damages the family foundation and that is why criminalizing in this case is considered in the group of anti-family crimes 
as an independent unit. This crime is of non-venal crimes and the government is responsible to pursue it, toward supporting the family foundation.

4) The crime for not registering of marriage, divorce and revocation of divorce directly refers to the family foundation. The criminalization of this criminal act has been done toward supporting the family foundation. In this case, the real victim is the family, because the crime for lack of registration of a marriage, divorce and revocation of divorce leads to disintegration of the family foundation.

The notable discussion in occurrence of this crime refers to its penalty that the legislator did not determine minimum for it and only talked about the maximum punishment, using the word "up to", actually the minimum punishment depends on the basic unit of punishment. With the expression "up to one-year prison" actually the legislator means being jailed from one day to one year imprisonment. So, according to article 726 of Penal Code, if someone helps the criminal, the court cannot imprison him for more than a day (Note 1) [10: p,163].

5) In the crime for under-age marriage which is of the public crimes, the family foundation is the real victim, because under-age marriage is not stable and a range of disorders occur in such families. Through criminalization, the legislator is going to support the family foundation, based on maturity and wisdom.

Considering that the law refers to maturity of girls to marry, if a woman marries an under-age boy, she is not subject to the above-mentioned article.

6) Obviously, if a family foundation form based on lies, the family will not be stable and soon or late, it will disintegrate. To prevent such occurrences, the legislator criminalized deception in marriage. Because, in formation of such families, family foundation will be the victim and even if it is formed, it will not be stable.

\section{Conclusion}

Criminal law falls in the area of general law and it is controlled by government. Entry of government into the privacy of the family should only happen in exceptional circumstances. According to Emil Durkin "we can say that the society has recourse to the guarantee of lawful executions if the other guarantees are insufficient" [11:p,73]. As we cannot impose our beliefs upon others through violence, punishment is also unable to keep marriage loyalty. Criminalization of nonpayment of life-cost is not a resolution, because the husband imprisoned by his wife's complains will strictly treat his wife and family after his release. Thus, decriminalization of the behavior is necessary. If individuals are taken into account as criminals, the consequences will be some inadequate, psychic, spiritual, social and family personality. The damages of criminalization of some actions are more than its benefits and use of the non-penal controlled systems as counseling and psychological systems are more effective.

In the case of family crimes, legislator has truly reduced the intensity of penal. It is because if the general aspect of the crime includes society, its private aspect includes family members in which they ignore it and do not get it too serious; therefore, any reduction and reconsideration of punishments in these groups of crimes are acceptable.

In the crime of immature marriage without parent's permission and court expediency, two points are noticeable: Can the immature accept responsibility of a family and cope with it? Evidently, the answer is negative. Thus, how the court can let the marriage contract of an incompetent person be concluded. Article 646 in the penal code and 1041 of civil code, which have determined imposition of immature marriage and marriage age and needs to fundamental amendment. Because marriage takes place in a higher age traditionally in one side and there are some contradictions in term of marriage age, maturity and legal age of development for modification and compatibility. In the other side, the punishment only includes men in the case of marriage with immature person whereas marriage of a woman with an immature son is not impossible.

Seemingly, the other criminalized behaviors related to the family institute have correctly been enacted. But recourse to the penal answer to settle the debates between family members is not the answer. Thus, in the process of investigation of family debates before their entry to the criminal procedure assume some resolutions as counseling and guidance system. In other words, they should passé a course of five sessions of family counseling; then, they come to the penal court if they did not reconcile.

If the family debates get entry into the penal court and resulting in a conviction, immediate execution of punishment only exacerbates the conflict. Thus, it is better to establish the training reformatory agencies as care suspense (delay) centers for criminals of some crimes as non-payment of alimony.

\section{References}

Ancel, M. (1996). sociald efense, trans. Ashori, Mohammad. Najafi ndabadi, Ali hossein. Tehran university 
publication

Ardabili, M. A. (2003). General criminal law (Vol. 1, 5th ed.). Mizan press.

Darvishmotavalli, J. (1999, Spring). Twenty mistakes in Islamic Penal Code. Journal of ministry of judiciary, (26).

Goldozian, I. (2005). Marginal notes on Islamic penal code (2nd ed.). Majd press.

Keynia, M. (2007). Principles of Criminology (Vol 2, 3rd ed.). Tehran University publication.

Madani, S. J. (2007). civil law (Vol. 8). family law,paydar publication, Tehran.

Mohghegh Damad, S. M. (2008). Islamic consideration of family law (15th ed). Islamic science publication center.

Raeijban Asli, M. (2005). Protective Victimology. Dadgostar press.

Safaei, S. H. et al. (2005). A Comparative study of family law. supervisor: Abolghasem Gorgi. University of Tehran press.

Safaei, S. H., \& Emami, A. (2007). A concise family law (12th ed.). Mizan publication.

Sherman, L. (n.d.). Challenge and Science of Penal Execution Guarantee. Trans. Ruholdin Kurdalivand. Law Journal of court, 33.

\section{Note}

Note 1. By virtue of paragraph 2, article 3 of collection law of government revenues and their application according to the law, ratified in 1995, the maximum imprisonment is more than 91 days and the minimum if less than 91 days and the court is able to imprison him for more than three months or fine him from 70001 Rials up to $3,000,000$ Rials.

\section{Copyrights}

Copyright for this article is retained by the author(s), with first publication rights granted to the journal.

This is an open-access article distributed under the terms and conditions of the Creative Commons Attribution license (http://creativecommons.org/licenses/by/3.0/). 